\title{
Demographic Diversity in the Board and Corporate Tax Planning in American Firms
}

\author{
ALIANI Khaoula \\ Higher institute of management of Tunis, Tunis \\ Tel: 216-9891-0575 E-mail: alianikhaoula@yahoo.fr \\ ZARAI Mohamed Ali \\ Higher institute of management of Tunis, Tunis \\ Tel: 9-665-3212-0061_E-mail: zaraimedali@yahoo.fr
}

Received: April 3, 2012 Accepted: April 30, 2012 Published: June 1, 2012

doi:10.5296/bms.v3i1.1851 URL: http://dx.doi.org/10.5296/bms.v3i1.1851

\begin{abstract}
This study examines the effect of demographic gender diversity on corporate tax planning. Using a sample of 300 firms (S\&P 500) for the 1996-2009 periods, results indicate that gender diversity on the board is not significant and doesn't have an effect on tax planning. Board independence enhances tax practice. ROA is significant and associated with tax planning. Board size and firm size do not exhibit significant relations. We contribute to the literature of gender by proposing a new tax framework. We propose new evidence for the paradigm of tax governance.
\end{abstract}

Keywords: Gender diversity, Demographic, Tax planning, Governance 


\section{Introduction}

The importance of improving the gender balance of corporate boards is increasingly recognized across the world. The firms miss a wide range of talents and experiences when women are under-represented on corporate boards.

During the latest decade, there has been an increasing interest on the gender of top executives and boards of directors of firms. The percentage of women in top management positions is still very low in most countries.

The Higgs (2003) report, in the UK, argues that diversity could enhance board effectiveness and specifically recommends that firms could benefit from professional women.

European countries are considering legislation that would force companies to promote more women to the executive positions. A new French law requires listed firms to reserve $40 \%$ of board seats for women by 2017. Norway and Spain have similar laws. Some countries, including France and Italy, are considering significant action and some, including Norway, Spain and Australia, have made significant steps already. while developing economies, such as India, China, and Middle East countries (Tunisia and Jordan) are beginning to recognize the importance of developing female talent up to the board level (Singh, 2008).

Despite the importance of corporate governance issues in the international agenda of various institutions in promoting good corporate practices across corporations in developed countries, there are few studies regarding the effects of board's attributes on corporate tax planning. Recently, Richardson et al., (2011) examine the effect of board's characteristics on corporate tax aggressiveness in the case of Australia. To our knowledge, we are the first who introduce the gender diversity in the study of tax planning in the American context.

We contribute to the existing literature on board diversity by establishing a link between gender diversity and the corporate tax planning strategy. We study the gender diversity from a tax perspective. In particular, we ask the following questions: does the gender composition of the board affect corporate tax planning in American firms? Are diverse boards better boards to improve tax planning?

The rest of this paper is organized as follows; section two presents a literature review on gender diversity. Section three describes the database. Section four presents the empirical methods. Section five exposes the results. Section six presents our discussions. Finally, section seven concludes.

\section{Prior literature on gender diversity}

Arfken et al., (2004) define diversity in corporate boards as difference in backgrounds. The directors of the board may have different points of views leading to a constructive debate and a better manner of resolving problems. Lückerath Rovers (2010) reviews several definitions of diversity. He concludes that gender diversity on the board represents one of multiple aspects of diversity. Van der Walt and Ingley (2003) defines diversity in the context of 
corporate governance as "the composition of the board and the combination of the different qualities, characteristics and expertise of the individual members in relation to decision-making and other processes within the board"

Poole (2001) notices that the increase of the number of women on corporate boards is closely related to the high awareness of shareholders, directors, and officers of a company of the importance of board diversity.

Gender diversity in firms can offer a set of benefits as additional knowledge, new ideas and insights to aid problem-solving, improving strategic planning, new knowledge or opinions, and experiences. (Arfken et al., (2004)

According to Finkelstein et al., (1996), the presence of women directors can potentially help the board accomplish its strategic role. The authors claim that women directors have a rich experience in the main needs of the firm. Then, the board executes its strategic function perfectly.

Several researchers are supporters of gender diversity perspective. Selby (2000) conclude that women presence on the American boards leads to diversity in experiences and values. Bilimoria and Wheeler (2000) and Mattis (2000) confirm the suggestions of Selby (2000) and state that women director's foster competitive advantage. They consider that women are able to deal effectively with diversity in product markets.

Prior research on diversity follows two fundamental distinctions: the demographic and the cognitive. ( Erhardt et al., 2003) In addition, Kilduff et al., (2000) argue that the research literature concerning the effects of group diversity on organizational outcomes reflects two different approaches. The first approach is referred as demographic; it concentrates on cognitive diversity in terms of proxy variables such as gender, age, ethnicity, and nationality. The demographic approach focuses on measurable attributes of individuals. The cognitive approach studies cognitive diversity through measuring attitudinal and normative differences between individuals. This second approach is interested in non observable variables. Nemeth (1986) concludes that individuals with different attitudes may be homogenous on demographic indicators. Thus, cognitive diversity in this literature refers to variability in unobservable attributes such as attitudes, values, and beliefs. Although attitudes and beliefs influence critically the tax behavior of individuals, we will focus in this study on demographic diversity, in particular the gender of directors sitting on the board.

We justify our choice of demographic diversity by the arguments discussed by demography researchers. Then, the reason to gather demographic rather than cognitive variables when examining the consequences of diversity is that "mental processes ... are more difficult to access and reliably measure" (Pfeffer 1983, p. 351).

Hambrick and Mason 1984, the pioneers of upper echelon theory, defend the demographic perspective. They consider that demographic variables, such as gender in our case are more objective and easily measured. Pfeffer (1983); Wiersema and Bantel (1992) corroborate this 
findings and argues that these observable variables yield more parsimonious explanations of organizational phenomenon.

The CEO's gender received little attention in the literature despite his importance in psychology and the studies of the organizational behavior. The research on the gender of the CEO concentrated typically on the implications of the female representation in the top management.

The gender diversity of the board improves the quality of discussions and increases its capacity to provide the better supervision of corporate reports. However, the gender diversity can reduce the effectiveness of the board while increasing the internal dissensions and constraining his capacity to act. (Gul et al., 2011)

The existing literature supports the first effect, it notes that the gender diversity of the boards is associated with the high quality of debates which are often considered unpleasant subjects for the exclusively masculine boards (Huse and Solberg, 2006; McInerney-Lacombe et al., 2008). The quality of the communication become more reinforced, which facilitates an important diffusion of information from the board of directors to investors. (Joy, 2008)

Adams and Ferreira (2009) suggest that women directors exercise an intensive monitoring on CEO through the increase of the percentage of presence in the meetings of the board. These authors show that women hold positions of monitoring in the audit, nomination and compensation committees.

Hambrick and Mason (1984) propose that gender is a demographic characteristic that can substitute the measure of the strategic results. However, little research treated the influence of the gender on CEOs. Earley and Mosakowski (2000) explain the impact of the gender heterogeneity of the management team on its performance.

Despite the importance of gender in studying tax compliance, a little prior literature was interested in this challenging stream of research. Fallan (1999) shows that differences at the level of the tax knowledge can affect attitudes towards taxation of men and women.

According to researchers of tax compliance, men show the tendency to be less compliant then women and have lower tax morale, defined as the willingness to pay taxes (Vogel, 1974; Aitken and Bonneville, 1980; Tittle, 1980; Torgler and Schneider, 2007). Ford et al., (1994); Reiss and Mitra (1998) discuss the evidence of gender differences in ethical decision making.

Croson and Gneezy (2009) show that the women are more risk averse, particularly in certain economic domains and they are involved less than men in non ethic behaviors. The research on the tax behavior suggests that women do not cooperate in tax evasion strategies. (Kastlunger et al., 2010)

According to the literature on the differences of risk taking behavior between the two genders and the tax compliance (Croson and Gneezy, (2009); Hasseldine, (1999), Kastlunger et al., (2010) suppose that women should expose higher levels of tax compliance. Yet, men should 
show important levels of tax evasion. The tendency of men for the tax evasion can be explained by several factors: the social differences that can be presented by the importance of gender in the orientation of the female and masculine concepts.

Kastlunger et al., (2010) signal that differences between women and men can be generated, not only by the biological differences, but particularly by a set of characteristics linked to the gender (the feminine traits: the socially desirable behavior, kindness; the masculine traits: the dominance, the competitiveness and aggressiveness). These authors suggest that the differentiations between men and women can be detected at the level of the tax compliance and the strategies of payments of tax burdens. Men are less conform that women and adopt a strategy while the payment of tax burdens.

The interpretation of the tax compliance of men and women will have to take in consideration the effects of the factors linked to the demographic gender or to the interest and the degree of implication facing the subject.

Aliani et al., (2011) were the first who introduce the issue of gender diversity and female values in Tunisia fiscal context. They conclude that the presence of women doesn't enhance the tax planning strategy within the firm.

Given the presented literature suggesting that diversity tends to generate new knowledge, innovation and quality decision-making in boards of directors, this study posits that similar findings may be found when studying gender diversity on the board and tax planning.

We propose to study the gender diversity in a context of tax governance; our study presents a new framework of research that examines the effect of demographic gender variable on the corporate tax planning.

\section{Empirical Method}

In this section, we present firstly the sample description. Secondly, we introduce the different categories of variables used in this paper. Thirdly, we expose our econometric model.

\subsection{Sample description}

We use a panel dataset on the board of directors in S\&P 500 firms from 1996-2009. The sample is based on 300 large American firms. Data is extracted from various sources. Financial accounting data is drawn from Compustat database and governance data is extracted from IRRC or proxy statements. The choice of our sample composed of S\&P 500 firms is based on the arguments introduced by Dyreng et al., 2008; Johnston, 2003; Minnick et Noga, 2010. These authors consider that larger firms manage their taxes more effectively. 


\subsection{Variable Definitions}

\subsubsection{Dependant variable}

ETR $_{\text {it: }}$ the effective tax rate, a proxy of corporate tax planning, measured as the report between the corporate tax income and the pretax income. Dyreng and al., (2010); Wilson (2009) used this variable in their studies of tax planning.

Following Minnick and Noga (2010), we focus on studying the firm's ability to manage its tax rate globally, not just domestically. Corporate tax planning is not necessarily associated to unethical or illegal behavior. Firms can legally reduce their tax burdens by using many provisions of tax codes.

\subsubsection{Independent variables}

$\mathbf{D I V}_{\text {it }}$ : The gender diversity of the board is measured in terms of percentage of women present in the board. In this study, demographic diversity was measured in terms of gender representation on boards. The diversity representation was obtained from the proxy statements of firms.

The gender diversity reinforces the mission of monitoring assigned to the board (Walsh and Seward, 1990) because women directors are in most of cases independent (Daily et al., 1999). M'hamid et al., (2010) suggest the necessity to integrate the variable gender diversity as a governance variable when studying the boards' attributes. The heterogeneity of the directors complicates the process of tax decision. Otherwise, the fiscal problems will not be resolved immediately because of the divergence of the group. Therefore, we suggest the following hypothesis:

Hypothesis a: There is a positive and significant relation between the gender diversity of the board and the tax planning.

IND $_{\text {it }}$ : this variable presents the percentage of the independent directors within the board of directors. A director is independent when he has no link of interest with the firm either his team. (Beasley and Petroni 2001; Fernández and Arrondo, 2005). The independence and the expertise of the external directors allow them to make objective decisions. Several researchers postulate that the increase of the number of independent directors within the board of directors improves the performance of the firm. Minnick and Noga (2010) show that the independent directors concentrate also on the reduction of the foreign taxes. They notice that the increase of the independent directors increases the domestic tax rates. Richardson and Lanis (2011) shows that firms having a high percentage of independent directors can reduce significantly the aggressive tax planning .

So, we suggest the following hypothesis

Hypothesis b: There is a positive and significant relation between the high presence of independent directors and corporate tax planning. 
BSI $_{\text {it }}$ : board size is measured by the logarithm of the total number of directors that compose the board. Richardson et al., (2011) use this variable in their study on corporate tax aggressiveness. Jensen (1993) believes that a smaller board of director plays a better monitoring function whereas a larger board of director is easier for the CEO to control.

We extend the findings of Jensen (1993) in a tax context and we suggest that a smaller board may be more favorable to tax planning strategies because the monitoring of the CEO becomes more intense. Then, the opportunistic behavior of the CEO is reduced, as a result of compression of interest conflicts.

We suggest the following hypothesis

Hypothesis c: there is a negative and significant relation between the board size and the corporate tax planning.

\subsubsection{Control variables}

In addition to the independent and dependent variables, we used two control variables. Based on firms 'characteristics, we involve return on assets and firm size in our study.

ROA ${ }_{i t}$ : the return on assets, defined as the report between the net income and the total of assets. Firms are interested in the tax optimization to improve the performance of the company. Dyreng et al., (2008) and Minnick and Noga (2010) employed this variable to control the performance and shed the light on the specific effect on the tax optimization.

SIZ $_{i t}$ : it is the size of the firm, measured by the natural Log of total assets.

The majority of the studies which treated the relation between effective tax rates and the firm size use this variable (Richardson and Lanis, 2007; Gupta and Newberry, 1997; Wu and Yue, 2006). We applied a $\log$ transformation to this variable to reduce the weight conferred on certain extreme values during parameter estimation of the model.

The call for the professionalization of boards meant that the skills criteria for candidates increasingly focused on the need to have substantial business and board level experience.

The low number of women on boards is in part a symptom of insufficient numbers emerging at the top of the management structure and the under-representation of women in senior management generally.

\section{Results}

\subsection{Descriptive Statistics}

Table 1 presents full-sample descriptive statistics for the variables described above. The average of the effective tax rate is 31.7 percent, this result is below the American statutory tax rate (35 percent). Then, on the basis of this percentage, we suggest that firms undertake tax strategies to minimize its tax burdens. We confirm the prior literature which postulates that statutory rates doesn't reflect the really tax burdens paid by firms. 
According to the table, we find an average of 10.828 directors composing the board of directors of the companies of our sample. Several studies showed that the optimal size of boards, in terms of performance, varies between 10 and 12. The minimal size of the board of directors is 4 . However, the large-sized boards of directors consist of 22 directors. We notice that boards of directors are strongly dominated by independent directors $(0.74 \%)$. Companies listed in the New York Stock Exchange and NASDAQ have a majority of independent directors.

As regards the variable board diversity, the average is $0.12 \%$, this result suggests that the American firms tend to diversify their boards of directors. The new tendency of the diversification of the american firms is due to the importance of the multiplicity of points of view and the perspectives of the directors to reach the efficiency. The progress of the female representation in boards of directors improved during these last years. The variable diversity presents a maximal value of $0.6 \%$, it is the case of the Avon company. The majority feminine presence can be proved by the nature of the corporate activity which is intended to produce the feminine products. The total absence of the feminine directors appears essentially before 2000 s when women's percentage was low.

Table 1.

\begin{tabular}{|c|c|c|c|c|c|}
\hline Variables & Observations & Moyennes & Ecart-type & Minimum & Maximum \\
\hline TIE & 3699 & 0.317 & 0.285 & -5.4 & 6.33 \\
\hline BSI & 3699 & 10.828 & 2.984 & 4 & 22 \\
\hline IND & 3699 & 0.746 & 0.175 & 0 & 16 \\
\hline DIV & 3699 & 0.120 & 0.096 & 0 & 0.6 \\
\hline
\end{tabular}

\subsection{Comparison Means test}

To set up the test of mean comparisons for the board diversification, we attribute the value 1 for companies having more than $20 \%$ of women who sit in the board of directors and 0 else. We aim at studying the difference in the effective tax rates, the board size and the percentage of the independent directors between diversified and homogeneous boards. 
Table 2.

\begin{tabular}{|c|c|c|c|c|c|c|}
\hline & & \multicolumn{5}{|c|}{ Mean comparions } \\
\hline & & & & & & Standard \\
\hline & & & & Sig. & Mean & Deviation \\
\hline & & $\mathrm{t}$ & $\mathrm{df}$ & bilateral & Difference & Difference \\
\hline $\mathbf{E T R}_{\text {it }}$ & $\begin{array}{c}\text { Hypothesis : equal } \\
\text { variances }\end{array}$ & 1.892 & 3876 & 0,059 & $-0,05380$ & 0,02843 \\
\hline \multirow[t]{2}{*}{ BSI $_{\text {it }}$} & Hypothesis unequal & & & & & \\
\hline & Variances & 0,4331 & 401,802 & 0,665 & 0,00741 & 0,01713 \\
\hline \multirow[t]{2}{*}{ IND $_{\text {it }}$} & Hypothesis : equal & & & & & \\
\hline & variances & 0,376 & 3696 & 0,707 & 0,01018 & 0,02707 \\
\hline
\end{tabular}

From the statistics presented above, we can assert that in priori:

- Companies having women in their boards of directors present the least effective tax rates that those to homogeneous boards of directors.

- The size of the diversified board of directors is not significantly different from that of the homogeneous board. The presence of the women within the board has no effect on the variation of its size.

- The percentage of the independent directors of diversified boards is not significantly different from that of the homogeneous boards. The feminine presence within board has no effect on its composition.

\subsection{Regression}

To examine the association between board of director attributes and corporate tax planning. We estimate the following regression model:

$$
\mathrm{ETR}_{\mathrm{it}}: \alpha+\alpha_{1} \mathrm{DIV}_{\mathrm{it}}+\alpha_{2} \mathrm{IND}_{\mathrm{it}}+\alpha_{3} \mathrm{BSI}_{\mathrm{it}}+\mathrm{ROA}_{\mathrm{it}}+\mathrm{SIZ}_{\mathrm{it}}+\varepsilon_{\mathrm{it}}
$$

Our methodological framework consists of three stage technique. In the first stage, we check the appropriate model of estimation. We have to test for the presence of individual effects of each Tunisian firm. In a second step, we specify whether the fixed effect or the random effect should be considered in estimating model parameters. The last step consists on estimating the coefficients of our variables.

We use the Fisher test, as a preliminary test, to verify the existence of individual effects in our sample. The p-value of this test entails the rejection of the null hypothesis (absence of individual effects). Therefore the Fischer test reveals the existence of specific effects across american firms. Consequently, our model is not homogeneous.

Then, we use the Hausman test to specify the nature of these individual effects. Thus, the Hausman test (1978) tests the null hypothesis which stipulates that the coefficients estimated 
by the efficient random effects estimator are the same as the ones estimated by the consistent fixed effects estimator. (Woolridge, 2001)

According to the results presented in table 3, we notice that the p-value of Hausman test is < 0.05 which means that random effects are non consistent. In fact, the fixed effects are privileged in our study. The econometrics of the panel data allows controlling the heterogeneity of the observations of our sample of American firms in their individual dimensions.

Table 3. Results of Hausman test

\begin{tabular}{|l|l|}
\hline \multicolumn{2}{|l|}{ Hausman test } \\
\hline Null Hypothesis & Difference in coefficients not systematic \\
\hline Prob $>$ chi2 & 0.004 \\
\hline
\end{tabular}

After setting up the effect of the econometric model, we are interested in verifying the absence of bias and problems that can affect the significance of the coefficients of the variables. We will make the necessary corrections if they exist. Among the potential problems that can arise at the time of our estimations, we quote essentially the heteroscedasticity and the multicolinearity .

We compute variance inflation factors (VIFs) when estimating our regression models to test for signs of multicolinearity between the independent variables. As no VIF exceeds five, multicolinearity is not problematic in our study (Hair et al., 2006).

Then, we apply Breusch-Pagan test to detect heteroscedasticity in our sample. The statistics of the test follows the chi square distribution. The "p-value" is less than the significance level $(5 \%)$, which leads us to reject the null hypothesis and to conclude the heteroscedasticity of our model.

To examine the association between effective tax rates and board characteristics, we estimate the following model using General least squares (GLS) to mitigate heteroscedasticity problems.

\section{Discussion}

This study investigated the relationship between demographic diversity of the board and corporate tax planning. As expected, the results supported the hypothesis stating that executive board of director independence was positively associated with corporate tax planning. This positive sign is confirmed by Richardson et al., (2011) and Minnick and Noga (2010). Thus, board independence appeared to have an impact on tax planning. We suggest that better corporate governance can enhance tax minimization strategies. 
Concerning the diversity variable, we conclude that the women presence in board of directors doesn't seem to have an effect on tax planning in American firms. This result can be explained by two reasons: the negligible percentage of women (12 percent in average) and the dominance of masculine strategies when elaborating tax planning. In order to benefit from diversity, firms have to increase women's percentage in their boards of directors. The women directors having a tax or accounting background may help the board to effectively manage its tax strategies.

ROA is positively associated with tax rates, this result with expectations since tax rates are progressive according to income. The positive sign is confirmed by Minnick and Noga (2010) and Aliani et al., (2011).

The variables BSI and SIZ (board size and firm size) are not significant. Thus, the board size doesn't have an effect on corporate effective tax rates. Our theoretical hypothesis is rejected and the result is contradictory to the research of Richardson et al., (2011) in the Australian context. In addition, the firm size is not significant. Despite the multiple researches linking firm size to corporate effective tax rates, there is no consensus about the sign of this variable. One possible explanation of the absence of significance is that previous studies on firm size employed this variable as an element of a set of firm's characteristics. However, in this study we used governance variables, then the effect of size become weak or even inexistent.

Table 4. Effect of the demographic gender on corporate tax planning

\begin{tabular}{|l|l|l|}
\hline Independent variables & \multicolumn{2}{|l|}{ Dependent variable : tax planning } \\
\hline & Coefficients & p-value \\
\hline DIV $_{\text {(it) }}$ & 0.10 & 0.632 \\
\hline IND $_{\text {(it) }}$ & -0.04 & 0.08 \\
\hline BSI $_{\text {(it) }}$ & 0.03 & 0.76 \\
\hline ROA $_{\text {(it) }}$ & 0.16 & 0.027 \\
\hline SIZ $_{\text {(it) }}$ & -0.011 & 0.641 \\
\hline Constant $_{\text {(it) }}$ & 0.41 & 0.129 \\
\hline Wald Khi (5) & 45.02 & 0.000 \\
\hline
\end{tabular}




\section{Conclusion}

The paper examines the effect of gender diversification of the board of directors on the corporate tax planning. Based on a sample of 300 American firms, we employ panel regression to test the hypothesis which stipulates that demographic gender diversity enhance tax planning. We find that gender diversity doesn't have an impact on the tax planning strategy due to the low percentage of women directors. The diversity in terms of opinions, knowledge and experience doesn't lead to a successful tax minimization practice. We conclude the predominance of men in tax planning strategies. Men are more experts in minimizing tax burdens; they act by using a strategy. The demographic diversity doesn't influence the attitude towards tax compliance.

We find that board independence, governance variable, improve tax practices. A better monitoring board boosts better corporate governance. Then, the agency problems would be reduced through an intensive control.

Overall, our study provides unique insights into the linking between gender diversity on the board and tax planning in the American context. Our paper contributes to extend the literature on the topic gender diversity. In addition, our findings help corporations to identify the fundamental factors that improve tax planning strategies. Finally, this study exposes a new angle of research for an emerging paradigm that links the characteristics of corporate governance to tax planning.

The further research will focus on the different aspects of diversity. The demographic diversity is not sufficient to study the tax planning. Cognitive approach of diversity may lead to consistent results. In particular, attitudes towards tax compliance influence the payment strategy of taxes.

\section{References}

Adams, R.B., \& Ferreira, D. (2009). Women in the boardroom and their impact on governance and performance. Journal of Financial Economics, 94, 291-309. http://dx.doi.org/10.1016/j.jfineco.2008.10.007

Aliani, K., M'hamid, I., \& Zarai, M. (2011)0 Diversité en genre dans le Conseil d'Administration et optimisation fiscale: validation dans le contexte tunisien. Global Journal of Management and Business Research, 11, 41-50.

Arfken, D., Bellar, S, \& Helms, M. (2004). The ultimate Glass Ceiling Revisited: The presence of women on corporate boards. Journal of Business ethics, 50, 177-186. http://dx.doi.org/10.1023/B:BUSI.0000022125.95758.98

Beasley, M. S., \& Petroni, K. R. (2001). Board Independence and Audit-Firm Type, Auditing: a journal of practice and theory, 20, 97-114. 
Bilimoria, D., \& Wheeler, J. (2000). Women Corporate Directors: Current Research and Future Directions. In M. Davidson and R. Burke (eds), Women in Management: Current Issues, Volume II. London: Sage, 138-163.

Croson, R., \& Gneezy, U., (2009). Gender differences in preferences. Journal of Economic Literature, 47(2), 1-27. http://dx.doi.org/10.1257/jel.47.2.448

Daily, C.M., Certo, S.T., \& Dalton, D.R., (1999). A decade of corporate women: some progress in the boardroom, none in the executive suite. Strategic Management Journal, 20(1), 93-100.

http://dx.doi.org/10.1002/(SICI)1097-0266(199901)20:1<93::AID-SMJ18>3.0.CO;2-7

Dyreng, S., Hanlon, M., \& Maydew, E. (2008). Long run corporate tax avoidance. The Accounting Review, 38, 61-82. http://dx.doi.org/10.2308/accr.2008.83.1.61.

Earley, P.C., \& Mosakowski, E., (2000). Creating hybrid team cultures: An empirical test of transnational team functioning. Academy of Management Journal, 43, 26-49

Erhardt, N. Werbel, J., \& Shrader, C., (2003). Board of director diversityand firm financial performance. Corporate governance: an international review, 11 (2), 102-111.

Eriksen, K., \& Fallan, L., (1996). tax knowledge and attitudes towards taxation: A report on a quasi- experiment. Journal of Economic psychology, 18, 387-402. http://dx.doi.org/10.1016/0167-4870 (96)00015-3

Fernández C., \& Arrondo R. (2005). Alternative Internal Controls as Substitutes of the Board of Directors. Corporate Governance Oxford, 3 (6), 856-866. http://dx.doi.org/10.1111/j.1467-8683.2005.00476.x

Finkelstein, S., \& Hambrick, D., (1996). Strategic Leadership: Top Executives and Their Effects on Organizations. St. Paul, MN: West.

Gupta, S., \& Mills, L., (2002). Corporate Mutistate Tax Planning: Benefits of Multiple Jurisdictions. Journal of Accounting and Economics, 33 (1), 117-139. http://dx.doi.org/10.1016/S0165-4101(01)00045-3.

Hambrick D.C., \& Mason P., (1984). Upper Echelons: The Organization as a Reflection of its Top Managers. Academy of Management Review, 9, 193-206.

Hasseldine, J. (1999). Gender differences in tax compliance, Asia-Pacific Journal of Taxation, 3, 73-89.

Huse, M., \& Solberg, A. G., (2006). Gender-related boardroom dynamics. How Scandinavian women make and can make contributions on corporate boards. Women in Management Review, 21(2), 113-130. 
Jensen, M.C. (1993). The modern industrial revolution, exit, and the failure of internal control systems. Journal of Finance, 48, 831-880. http://www.blackwell-synergy.com/doi/abs/10.1111/j.1745-6622.1994.tb00244.x

Joy, L., (2008). Women board directors in the United States: An eleven year retrospective. In S. Vinnicombe, V. Singh, R. J. Burke, D. Bilimoria, \& M. Huse (Eds.), Women on corporate boards of directors: International research and practice, 15-23.

Kastlunger, B., Dressler, S., Kirchler, E., Mittone, L., \& Voracek, M., (2010). Sex differences in tax compliance: Differentiating between demographic sex, gender-role orientation, and prenatal masculinization (2D:4D). Journal of economic psychology, 31, 542-552.

Kilduff, M., Angelmar, R., \& Mehra, A., (2000). Top Management-Team Diversity and Firm Performance: Examining the Role of Cognitions, Organization Science, 11, 21-34. doi: 10.1287/orsc.11.1.21.12569.

Lückerath, R. (2010). Women on board and firm performance. SSRN working paper.

M'hamid, I., \& Hachana, R. (2010). Diversité en genre au top management, Divulgation des valeurs féminines et performance, l'exception Tunisienne. Global Journal of Strategies and Governance, 1(2), 3-23.

Mattis, M. C. (2000). Women Corporate Directors in the United States. In R. Burke and M. Mattis (eds), Women on Corporate Boards of Directors. Netherlands: Kluwer Academic, 43-56.

McInerney-Lacombe, N., Bilimoria, D., \& Salipante, P. F., (2008). Championing the discussion of tough issues: How women corporate directors contribute to board deliberation. In S. Vinnicombe, V. Singh, R. J. Burke, D. Bilimoria \& M. Huse (Eds.), Women on corporate boards of directors. Northampton, MA: Edward Elgar

Minnick, K., \& Noga ,T. (2010). Do corporate governance characteristics influence tax management?. Journal of corporate finance, 16, 703-718., http://dx.doi.org/10.1016/j.jcorpfin.2010.08.005

Nemeth, C.J., (1986). Differential contributions of majority and minority influence. Psychological Review, 93, 23-32. http://dx.doi.org/10.1037/0033-295X.93.1.23

Poole, S. M., (2001). Women Now on 36\% of Georgia Corporate Boards. The Atlanta Journal Constitution (September 29), E6.

Richardon, G \& Roman, L., (2011). The effect of board of directors composition on corporate tax aggressiveness. Journal of accounting and public policy, 30, 50-70. http://dx.doi.org/10.1016/j.jaccpubpol.2010.09.003.

Richardson, G. (2007). Determinants of the variability in corporate effective tax rates and tax reform: Evidence from Australia. Journal of Accounting and Public Policy, 26 (6), 689-704. 
Selby, C. C. (2000). From Male Locker room to Coed Board Room: A Twenty-five Year Perspective.In R. Burke and M. Mattis (eds), Women on Corporate Boards of Directors. Netherlands: Kluwer Academic, 239-251.

Singh, V. (2008). Contrasting positions of women directors in Jordan and Tunisia. In: Vinnicombe, S., Singh, V., Burke, R., Bilimoria, D. and Huse, M. (eds.) Women on Corporate Boards of Directors: International Research and Practice, 165-85.

Walsh, J.P., \& J.K., Seward., (1990). On the efficiency of internal and external corporate control mechanisms. Academy of Management Review, 15, 421-458.

Walt, N. van der \& Ingley, C. (2003). Board Dynamics and the Influence of Professional Background, Gender and Ethnic Diversity of Directors. Corporate Governance, 11(3), 218-234. http://www.blackwell-synergy.com/doi/abs/10.1111/1467-8683.00320

Wiersema, M. F., \& Bantel, K. A. (1992). Top management team demography and corporate strategic change. Academy of Management Journal, 35, 91-121

Wilson, R. (2009). An examination of corporate tax shelter participants. The accounting Review, 84, 969-999. http://dx.doi.org/10.2308/accr.2009.84.3.969 